\section{ANNALS OF THE UNIVERSITY OF CRAIOVA}

Series: $\begin{aligned} & \checkmark \text { Biology } \\ & \checkmark \text { Horticulture } \\ & \checkmark \text { Food products processing } \\ & \text { technology } \\ & \checkmark \text { Environmental engineering }\end{aligned}$

Vol. XXVI (LXII) - 2021

\title{
RESEARCH ON THE DYNAMICS OF HEART DESEASE
}

\author{
Olaru Mariana Luminiţa ${ }^{1 *}$, Stamin Florin Daniel ${ }^{2}$ \\ ${ }^{1}$ University of Craiova, Faculty of Horticulture, Biology and Engineering Department, \\ Al.I.Cuza Street, No. 13, 200585, Craiova \\ ${ }^{2}$ University of Craiova, Master student, Faculty of Horticulture, The Natural Ecosystems Evolution \\ and the Conservation of Biodiversity \\ * Correspondence author. E-mail: luminitaolaru@yahoo.com
}

Keywords: heart, pump, blood, heart cells, muscle fibers

\begin{abstract}
Located in the rib cage, the propulsion organ of the circulatory system has a vital role in performing the functions of organisms. Being considered a real pump, the heart is included in both types of circulatory systems. Through its muscle structure, it combines two functions: an electrical and a mechanical one, both with the help of the component electrical cells and with the help of the contractions and relaxations that it produces.

The evolution of cardiology and methods of medical investigation has led to the possibility of recording cardiac activity and detecting various types of diseases, which can destabilize the activity of the heart and, if not detected and treated in time, can even lead to the death of the body.
\end{abstract}

\section{INTRODUCTION}

Maintained in a serous called the pericardium, the heart is located in the middle mediastinum, between the two lungs, above the diaphragm, anterior to the esophagus and thoracic aorta, and posterior to the sternum and costal cartilage. (Nicolescu \& Albulescu 2010).

Musculocavitary organ with the role of suction-repellent pump, the heart consists of three layers: the outer layer - the epicardium, belongs to the pericardium; the middle muscular layer - the myocardium; the inner layer - the endocardium, which lines the heart cavities. (Jianu et al. 2018)

Morphologically, the heart is structured in four cavities: two atria and two ventricles, and functionally, it is divided into two halves, the right heart and the left heart. (Furnică \& Tinică 2015)

The right atrium communicates with the right ventricle through the right atrioventricular orifice, endowed with the right atrioventricular valve (tricuspid valve) formed, in turn, by three cusps: anterior, posterior, septalThe left atrium communicates with the left ventricle through the left atrioventricular orifice endowed with the left atrioventricular valve (bicuspid valve) consisting of two cusps (anterior and posterior). Due to its episcopal miter-like appearance, it is also called the mitral valve. The ventricles are pyramidal in shape, are separated by the interventricular septum and pump blood into the two blood circuits. (Caterniuc et al. 2015).

The heart is irrigated by the two coronary arteries (left and right), originating in the ascending aorta. Collateral branches detach from the coronary arteries, which 
are of the terminal type, irrigating certain territories of the myocardium, without joining with the neighboring collateral branches. If one of these collaterals becomes obstructed, the territory is no longer vascularized, necrotic and a heart attack occurs. The venous blood of the heart is collected by the coronary sinus, located in the left atrioventricular groove and opening into the right atrium.

The innervation of the heart is provided by the cardiac nerves, coming from the vagus nerve (parasympathetic vegetative nervous system) and the cervical sympathetic. (Djamo 2007)

The heart can be thought of as an electrical system that rhythmically generates contractile impulses and a mechanical system that reacts to these impulses through rhythmic contractions. In order to be able to exercise its "pump" function, it is necessary to have a perfect correlation between the electrical and mechanical activity of the heart. (Năstăsescu \& Ungureanu 1999).

Cardiac electrical phenomena (pulse formation) precede cardiac contraction, which can be studied in cardiac cells (cardiac potentials) or in the whole heart in the form of an electrocardiogram, which highlights the algebraic sum of potential changes of all myocardial fibers during cardiac activity ( cardiac cycle).

Cardiac tests include electrocardiogram, cardiac radiography, cardiac ultrasound, radioisotopic scintigraphy, catheterization and coronary angiography. (Cinteză 2005).

\section{MATERIAL AND METHODS}

The dynamics of heart disease are varied, so they can be found: heart malformations - represents about $5 \%$ in heart disease, tumor lesions - rare, dystrophic lesions - the consequence of local or general disturbance of various metabolisms, circulatory lesions - such as myocardial infarction, inflammatory lesions (Simionescu 2004), cardiomyopathies, hypertension and hypotension (Borundel 2019).

This paper is based on a retrospective statistical study conducted on a group of patients with heart disease. The anamnestic study aimed to follow the susceptibility factors that increase the risk of heart disease, namely: gender, age, background, and level of education. The study was performed for a period of 6 months (September 2019 - February 2020), on a group of 100 patients who presented in the specialized outpatient clinic of the Craiova County Emergency Clinical Hospital, during the period mentioned above.

The individuals in the study group were divided according to clinical criteria, as well as according to epidemiological criteria - sex (women and men), age group (15-30 years, 31-40 years, 41-50 years, 51-60 years, $61-70$ years and the group over 70 years), the environment of origin (urban and rural) and the level of education (gymnasium, secondary, higher), entered in the observation sheet of each patient.

Through the statistical processing of the results from the analysis bulletins, a database was created which was used to represent them graphically and tabularly, to interpret and discuss the results, as well as to conclude by reading them.

\section{RESULTS AND DISCUSSIONS}

An analysis of the dynamics according to the gender of the patients in the studied group showed an unbalanced impairment, the percentage of women with cardiovascular diseases (62\%), being almost double that of men (38\%) (Table 1, Figure 1). 
Table 1

Dynamics of patients with cardiovascular disease by age group and gender

\begin{tabular}{|l|l|l|l|}
\hline $\begin{array}{l}\text { Age } \\
\text { group }\end{array}$ & $\begin{array}{l}\text { Number of } \\
\text { patients }\end{array}$ & Female & Male \\
\hline $15-30$ & $9(9 \%)$ & $7(7 \%)$ & $2(2 \%)$ \\
\hline $31-40$ & $12(12 \%)$ & $7(7 \%)$ & $5(5 \%)$ \\
\hline $41-50$ & $15(15 \%)$ & $8(8 \%)$ & $7(7 \%)$ \\
\hline $51-60$ & $19(19 \%)$ & $10(10 \%)$ & $9(9 \%)$ \\
\hline $61-70$ & $21(21 \%)$ & $13(13 \%)$ & $8(8 \%)$ \\
\hline Over 71 & $24(24 \%)$ & $17(17 \%)$ & $7(7 \%)$ \\
\hline Total & $100(100 \%)$ & $62(62 \%)$ & $38(38 \%)$ \\
\hline
\end{tabular}

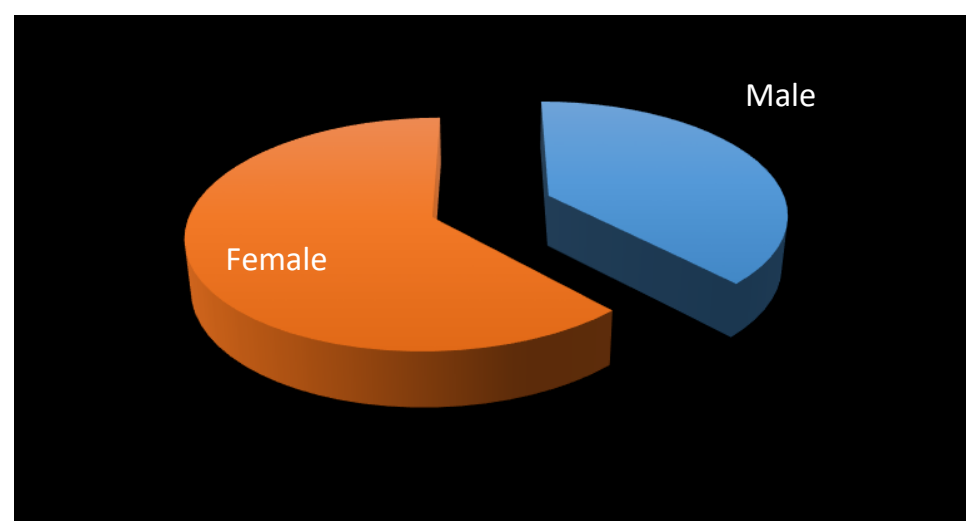

Figure 1. Dynamics of patients with cardiovascular disease by age group and gender

These results can be compared with data from the literature, which indicates that the risk of death from the acute coronary syndrome or heart attack is higher in women than in men, according to the latest data published in an article published in "Journal of the American Medical Association" (Jama), signed by researchers at New York University School of Medicine (USA). Maria Grazia Modena, director of the Institute of Cardiology at the University of Modena and Reggio Emilia, also says that the protection against cardiovascular disease conferred by estrogen during the fertile period has its price. In men, coronary heart disease begins earlier, which allows them to adapt, responding through natural bypasses, small lateral pathways in the blood vessels. This is an advantage because in the event of a heart attack, their body can activate these secondary microcircuits. With the onset of menopause, however, the woman is unexpectedly exposed to a number of risk factors - hereditary, due to lifestyle (such as smoking and stress) or physiological (such as increased abdominal fat, hypertension or diabetes).

(http://www.descopera.ro/stiinta/7951794-barbatii-si-femeile-inegali-si-n-fata-bolii)

Regarding the distribution of patients according to age group and sex, it can be seen that the most affected age groups are those between 51-60 years (19 cases, of which 10 women and 9 men), 61-70 years (21 cases, of which 13 women and 8 
men) and especially the past 71 years group (24 cases, of which 17 women and 7 men). The fewest cases were found in the 15-30 age groups (9 cases, of which 7 women and 2 men), 31-40 years (12 cases, of which 7 women and 5 men) and 41-50 years (15 cases, of which 8 women and 7 men). This distribution shows us that, with age, the risk of heart disease increases due to various harmful external factors, which accumulate and affect the heart (alcohol, tobacco, coffee, inadequate nutrition, etc.). (Table 1, Figure 2).

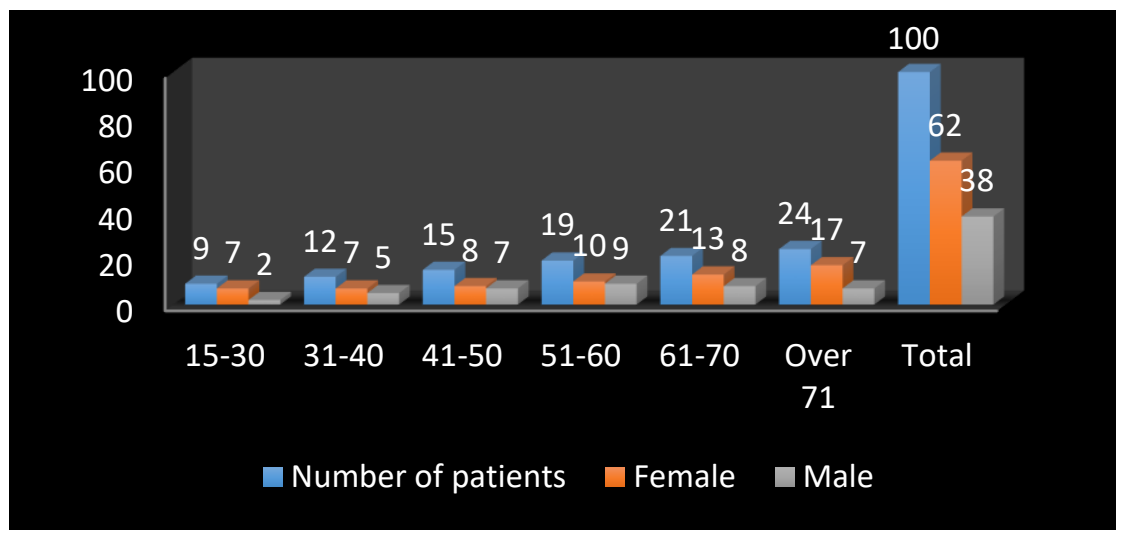

Figure 2. Dynamics of patients with cardiovascular disease by age group and gender

Regarding the dynamics according to the environment of origin of the patients in the study group, 60 came from urban areas (32 women and 28 men) and 40 came from rural areas (10 women and 30 men), which demonstrates a higher frequency. high levels of disease in the city, probably due to inadequate nutrition consumed by city dwellers. On the other hand, patients in rural areas often go to the doctor only in extreme cases (Table 2, Figure 3).

Patient dynamics according to the environment of origin

\begin{tabular}{|l|l|l|l|}
\hline & Female & Male & Total \\
\hline Rural & $10(10 \%)$ & $30(30 \%)$ & $40(40 \%)$ \\
\hline Urban & $32(32 \%)$ & $28(28 \%)$ & $60(60 \%)$ \\
\hline Total & $62(62 \%)$ & $38(38 \%)$ & $100(100 \%)$ \\
\hline
\end{tabular}




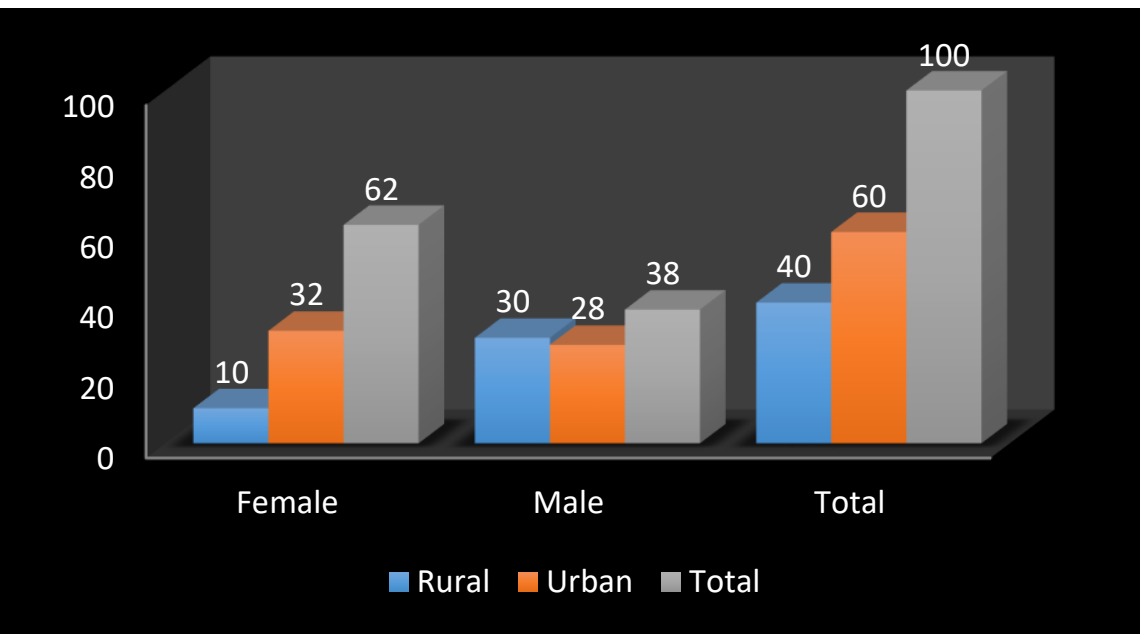

Figure 3. Patient dynamics according to the environment of origin

Interesting results from the point of view of population health education were obtained by analyzing the group in terms of the level of education. The majority of the sample consists of 52 patients with secondary education (52\%), while only 6 patients (6\%) have higher education. A significant percentage of $42 \%$ (42 patients) is represented by people with primary education, which raises a serious question mark on the level of health education of this category of patients. In this context, it is possible that these people have not realized the danger of the disease (Table 3 , Figure 4).

Table 3

Distribution of patients according to the level of education

\begin{tabular}{|l|l|l|l|l|}
\hline Level of study & $\begin{array}{l}\text { Gymnasium } \\
\text { studies }\end{array}$ & $\begin{array}{l}\text { Medium } \\
\text { studies }\end{array}$ & $\begin{array}{l}\text { Higher } \\
\text { studies }\end{array}$ & Total \\
\hline Number of cases & $42(42 \%)$ & $52(52 \%)$ & $6(6 \%)$ & $100(100 \%)$ \\
\hline
\end{tabular}

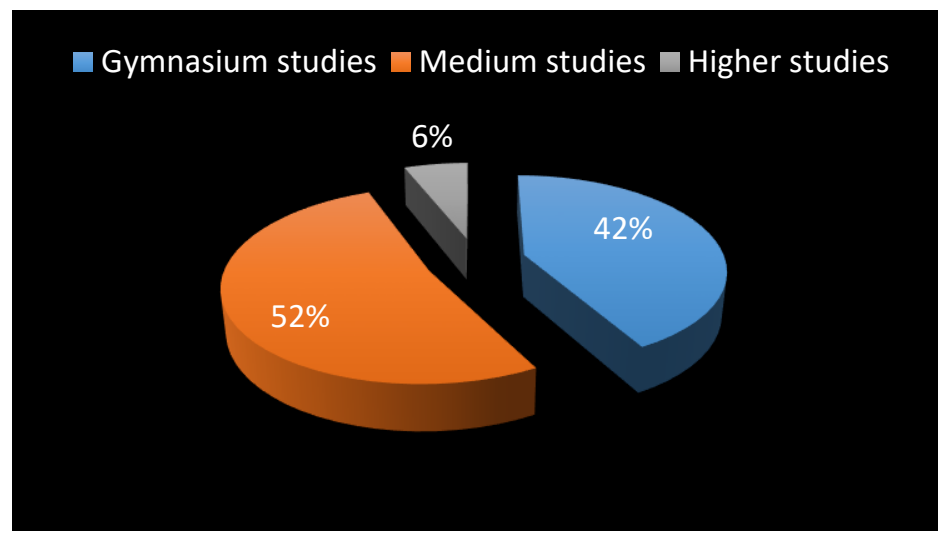

Figure 4. Distribution of patients according to the level of education 


\section{CONCLUSIONS}

According to the study, from the point of view of the distribution of cases by sex, there is an unbalanced impairment, the percentage of women with heart disease being double that of men.

Analyzing the distribution of patients by age groups, it was observed that the most affected age groups are those over 50 years, which shows that with age, the risk of heart disease increases due to various harmful external factors, which accumulate. and affects the heart (alcohol, tobacco, coffee, inadequate nutrition, etc.). Most cases were found in urban areas, and the fewest cases were found in rural areas, which demonstrates a higher frequency of diseases in the city, probably due to inadequate nutrition consumed. by city dwellers. However, this result is also because patients in rural areas often go only in extreme cases to the doctor.

Another interesting aspect is the distribution of the group in terms of the level of education, which calls into question the knowledge about heart disease and health education of these people, being a way to intervene through better information and popularization of prophylactic and hygienic measures. The majority sample consisted of patients with secondary and primary education, while only a small percentage $(6 \%)$ were registered with higher education. The patient's level of training qualifies him to be able to understand the danger of heart disease, to discern the importance of presenting to the doctor for control and investigations, to understand the need for medical urgency for diagnosis and treatment. The patient with a higher level of training, through documentation, knows what are the consequences of delaying the addressability to the doctor and acts accordingly.

In order to achieve a more efficient health education, adequate to the level of understanding, the method of advertising information is not at all inefficient.

\section{REFERENCES}

Borundel C. 2019. Manual de medicină internă pentru cadre medii. Edit. ALL Bucureşti.

Caterniuc I., Lupașcu T., Batîr D., Bendelic Anastasia, Globa L., Zorina Zinovia, Babuci Angela, Certan Galina, Globa Tatiana 2015. Anatomia omului (culegere de cursuri pentru Facultatea Farmacie). Edit. Tipografia-Sirius, Chișinău.

Cinteză M. 2005. Ce-i cu inima mea doctore?. Edit. Humanitas, București.

Djamo Olga (2007). Anatomie. Edit. Fundației România de Mâine, București.

Jianu Adelina Maria, Motoc A., Roșu Luminioara, Stana Loredana, Ilie C. 2018. Anatomia omului Volumul IV: Cavitatea toracică Semestrul II. Edit. „Victor Babeș”, Timișoara.

Năstăsescu Gh., Ungureanu Luminiţa 1999. Fiziologia animalelor. Curs universitar, Vol. II. Edit. Sitech, Craiova.

Nicolescu luliana, Albulescu Dana Maria 2010. Anatomia omului. vol. I, Edit. Medicală Universitară, Craiova.

Simionescu Cristiana 2004. Anatomie patologică. Edit. Medicală Universitară, Craiova.

Tinică G., Furnică Cristina 2015. Cordul - Anatomie clinică și chirurgicală. Edit. Universității „A. I. Cuza”, Iași. bolii

http://www.descopera.ro/stiinta/7951794-barbatii-si-femeile-inegali-si-n-fata- 